\title{
Mus308 Processes Oxygen and Nitrogen Ethylation DNA Damage in Germ Cells of Drosophila
}

\author{
Nancy Díaz-Valdés, ${ }^{1,2}$ Miguel A. Comendador, ${ }^{1}$ and L. María Sierra ${ }^{1}$ \\ ${ }^{1}$ Área de Genética, Departamento de Biología Funcional e Instituto Universitario de Oncología del Principado de Asturias (IUOPA), \\ University of Oviedo, 33006 Oviedo, Spain \\ 2 Área de Hepatología y Terapia Génica, Centro de Investigación Médica Aplicada (CIMA), University of Navarra, \\ 31008 Pamplona, Spain
}

Correspondence should be addressed to L. María Sierra, lmsierra@uniovi.es

Received 13 May 2010; Revised 27 July 2010; Accepted 2 September 2010

Academic Editor: Shigenori Iwai

Copyright ( $\odot 2010$ Nancy Díaz-Valdés et al. This is an open access article distributed under the Creative Commons Attribution License, which permits unrestricted use, distribution, and reproduction in any medium, provided the original work is properly cited.

The D. melanogaster mus308 gene, highly conserved among higher eukaryotes, is implicated in the repair of cross-links and of Oethylpyrimidine DNA damage, working in a DNA damage tolerance mechanism. However, despite its relevance, its possible role on the processing of different DNA ethylation damages is not clear. To obtain data on mutation frequency and on mutation spectra in mus308 deficient (mus308-) conditions, the ethylating agent diethyl sulfate (DES) was analysed in postmeiotic male germ cells. These data were compared with those corresponding to mus308 efficient conditions. Our results indicate that Mus308 is necessary for the processing of oxygen and N-ethylation damage, for the survival of fertilized eggs depending on the level of induced DNA damage, and for an influence of the DNA damage neighbouring sequence. These results support the role of mus308 in a tolerance mechanism linked to a translesion synthesis pathway and also to the alternative end-joinig system.

\section{Introduction}

Among the genes identified so far in Drosophila melanogaster that play a role in DNA damage repair, mus308 presents some unique properties, because its CDNA sequence shows motifs characteristic of DNA helicase and DNA polymerases [1]. The putative product of this gene was indeed isolated as a new DNA polymerase, homologue to the Escherichia coli DNA polymerase I, carrying as well a DNA helicase domain at the $\mathrm{N}$ terminus region [2]. Orthologues of this gene have been found in Caenorhabditis elegans [1], Arabidopsis thaliana [3, 4], and mammals [3, 5-9]. In humans, three genes encoding proteins with sequence similarities to Mus308-one similar to Mus308 helicase, HEL308 [3], and two similar to the Mus308 polymerase, POLQ $[5,7]$ and POLN [6] - have been identified to date. POLQ, the most studied of these proteins, has also an ATPasehelicase domain at the $\mathrm{N}$ terminus and is able to perform DNA synthesis past an abasic site, following the A-rule [10]; however, there are contradictory results about its fidelity in a normal nondamaged template $[10,11]$.

The mus 308 gene is involved in the repair of cross-linking adducts $[12,13]$ and also of monofunctional damage [13], probably persistent and difficult to repair by other systems, such as the O-ethylpyrimidine damage induced by N-ethyl$\mathrm{N}$-nitrosourea (ENU) in postmeiotic male germ cells [14]. In addition, at least parts of ENU- and diethyl sulphate- (DES-) induced damages were repaired by Mus308 in female germ cells of Drosophila [15]. This protein works in a damage bypass mechanism $[1,13]$, which was originally related to homologous recombination, HR $[14,16]$. Nevertheless, the isolation of the DNA polymerase encoded by this locus [2], its possible ability for DNA synthesis through abasic sites $[10,11]$, and the requirement of a functional Mus308 protein to prevent damage-induced DNA strand breaks in vivo in somatic cells of Drosophila [17], pointing to a translesion synthesis (TLS) mechanism as the activity of this protein [17]. In summary, along these years the 
work of our laboratory have demonstrated that Mus308 works in the repair/processing of cross-links and oxygen ethylation damage $[13-15,17]$ whereas $\mathrm{N}$-ethylation damage is apparently not substrate of this system, because no effect of methyl methanesulphonate (MMS) was detected either in germ cells [13] or in somatic ones [17]. Additionally, its mechanism of action is poorly understood, because it could be related to HR $[14,16]$ or to TSL [17]. Because of this, we have proposed that the mus308 locus works in a bypassmediated tolerance mechanism, BTM $[15,17]$.

Given the conservation of mus308 among higher eukaryotic organisms, this locus is likely a part of a repair system relevant to DNA damage processing. Therefore, it would be important to elucidate what types of DNA damage, apart from cross-links and O-ethylpyrimidine adducts, are substrate of this system and to get information about which of the two possible mechanisms of action, HR or TLS, is actually involved in the damage bypass process.

To have more information about the role of Mus308 in the processing of DNA ethylation damage, we have studied here the effect of DES in postmeiotic male germ cells, analysing maternal repair and using the vermilion system [18]. This system combines the analysis of induced mutation frequencies, both at a single locus (vermilion, with a specific locus test) and at multiloci (700 loci in the X-chromosome, with the recessive lethal test), with the generation and analysis of mutation spectra [18]. Our data, together with other already published, indicate that Mus308 protein is involved in the processing of all types of oxygen ethylation damage, that it is also involved in the processing of nitrogen ethylation damage, that it prevents cell death at least when the amount of DNA damage is high, and that this protein could be working in a TLS mechanism as well as in an alternative end-joining system (alt-EJ).

\section{Material and Methods}

2.1. Chemicals. DES (CAS no. 64-67-5), obtained from Sigma Química (Spain), was dissolved in a solution of $3 \%$ ethanol-1\% Tween-80 in $33.1 \mathrm{mM}$ phosphate buffer (16.5 $\mathrm{mM} \mathrm{Na}_{2} \mathrm{HPO}_{4}, 16.6 \mathrm{mM} \mathrm{KH}_{2} \mathrm{PO}_{4}, \mathrm{pH} 6.8$ ), containing $5 \%$ sucrose.

2.2. RL Test and Isolation of Vermilion Mutants. 1-2-days old brown (bw) males, in groups of 30 individuals, were placed in glass tubes, with eight layers of glass microfiber paper (Whatmann, GF/A) at the bottom, soaked with $0.9 \mathrm{ml}$ of different DES concentrations. Negative controls were carried out treating males only with the solvent solution. After 3 hours treatment, males were mated to $\operatorname{In}(1) s c^{S} 1 L s c^{8} R \operatorname{In}(1) d l^{\prime}-{ }^{\prime} 49, y, s c^{S 1} s c^{8}, v ; b w ; m u s 308^{D 2}$ $(I, v ; b w ; m u s 308)$ virgin females (for marker descriptions see [19]). Protocols for fractionation the progeny in mature sperm and spermatids for the recessive lethal (RL) test and for isolation of $F_{1}$ and $F_{2}$ vermilion $(v)$ mutants were described elsewhere [14].

At least five different experiments were carried out for each concentration and, since there were no differences among them, data were pooled. Statistical analysis of RL results was performed comparing mutant frequencies in treated flies with their respective negative controls, using the Fisher exact test.

The influence of mus308 in the repair or processing of ethylation-induced damage was measured through the mutability index (MI) [20], and the statistical analysis of Aguirrezabalaga et al. [13] was carried out to determine whether MI values significantly differed from 1 .

2.3. Molecular Analysis of Mutations. For each transmissible vermilion mutant, a homozygous strain was established to carry out the molecular analysis. All the isolated mutants were analysed.

The isolation of DNA and PCR amplifications were as described [21]. Mutant vermilion genes were cloned in the M13mp19 vector or in a $p U C 18$ plasmid [22]. Sequencing reactions for the coding region were carried out using the dideoxy method, with a set of 10 internal primers. A fragment of about $1.8 \mathrm{~Kb}$, localized upstream of the coding region, was analyzed as described before [21] in those mutants which did not show changes in the coding sequence. In order to exclude Taq polymerase-introduced errors, at least two plaques or colonies from independent PCR reactions were sequenced for each mutant.

Statistical analyses of differences between mutation spectra were carried out using the hypergeometric test for comparison of samples from mutational spectra $[23,24]$.

\section{Results and Discussion}

3.1. RL and Vermilion Mutation Frequencies. The RL and vermilion mutation frequencies, both spontaneous and induced by the different DES concentrations under mus308 deficient $\left(m u s 308^{-}\right)$conditions, are presented in Table 1. Pooled data from mature sperm and spermatids are shown, because no differences between them were found in any case (not shown).

All chemically induced RL mutation frequencies are statistically higher than the spontaneous one, although their values decrease as DES concentration increases. Comparisons with the results previously obtained in mus308 proficient $\left(\right.$ mus $\left.308^{+}\right)$conditions [25] reveal two relevant differences (Table 1). First, the spontaneous RL frequency is statistically lower in $m u s 308^{-}$than in $m u s 308^{+}$conditions. Second, in mus $308^{-}$conditions, a decrease in RL frequencies is induced as DES concentration increases, whereas the opposite, that is an increase was detected in efficient repair conditions. Consequently, the value of the mutability index (MI) for $10 \mathrm{mM} \mathrm{DES}$ is statistically higher than 1 whereas for $15 \mathrm{mM}$ and $25 \mathrm{mM}$ the MIs are lower than 1 (Table 1).

To analyse the dose range between 10 and $15 \mathrm{mM}$ DES, and to compare both repair conditions in the same experiment, a new and small experiment was carried out with $12 \mathrm{mM}$ concentration. The obtained results confirmed that when the amount of DNA damage is low or moderate, hypermutability is obtained $(4.8 \%$ and $8.2 \%$ RL mutation frequencies in $m u s 308^{+}$and in $m u s 308^{-}$, respectively, with 
TABLE 1: Recessive lethal (RL) and $v$ mutation frequencies induced by DES on postmeiotic male germ cells of D. melanogaster, under mus308 deficient $\left(m u s 308^{-}\right)$and efficient $\left(m u s 308^{+}\right)$conditions. Values of mutability index (MI) and their statistical signification are also presented.

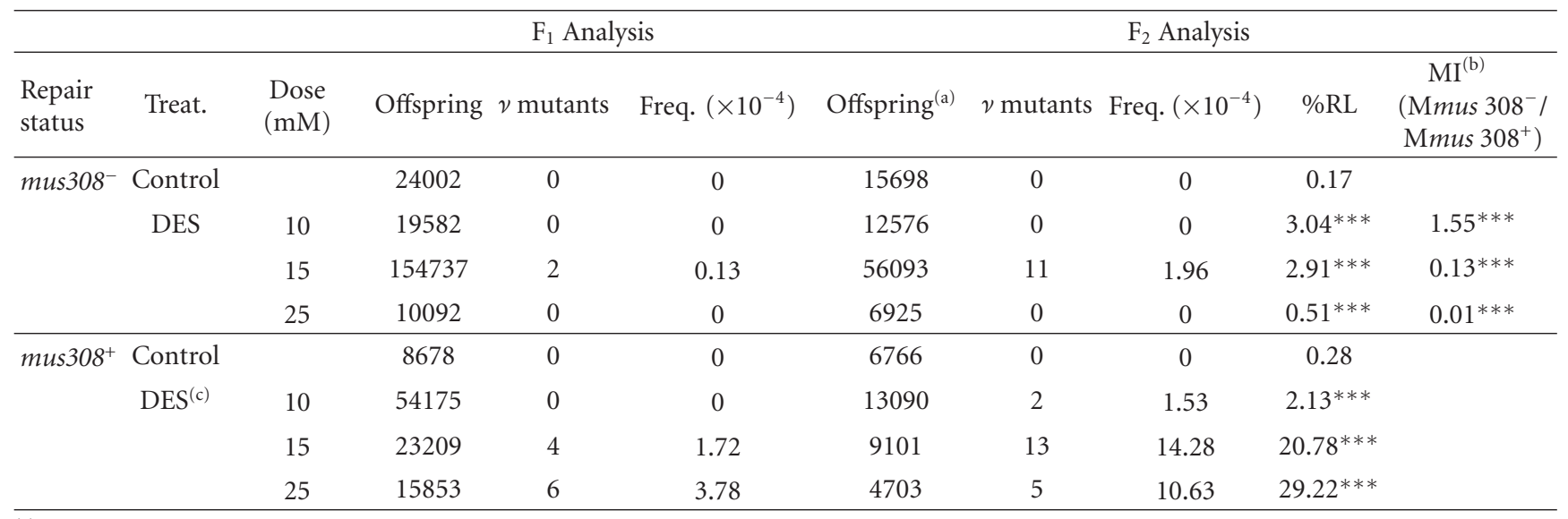

(a) The $\mathrm{F}_{2}$ offspring is the number of nonsterile treated $\mathrm{X}$-chromosomes

(b) MI: mutation frequency induced in $m u s 308^{-} /$mutation frequency induced in mus $308^{+}$

(c) Data from Sierra et al. [25]. One experiment was carried out mating the treated males to $I, v ; b w$ females to check the validity of these previous data for comparisons.

${ }^{*} P<.05 ; * * P<.01 ; * * * P<.001$.

TABLE 2: Molecular characterization of $v$ mutants induced by DES in postmeiotic male germ cells, under mus $308^{-}$conditions.

\begin{tabular}{|c|c|c|c|c|c|}
\hline Mutant & Brood & Position & Mutation & Change & Sequence $\left(5^{\prime}-3^{\prime}\right)^{(\mathrm{a})}$ \\
\hline D8-4 & $\mathrm{F}_{2}-1 \mathrm{~B}$ & $92-556$ & 464 bp deletion & & \\
\hline D8-5 & $\mathrm{F}_{2}-1 \mathrm{~B}$ & 566 & CG-TA & Leu-Phe & ACAG C TCCTG \\
\hline \multirow[t]{5}{*}{ D8-6 } & $\mathrm{F}_{2}-1 \mathrm{~B}$ & 6 & TA-AT & Ser-Arg & TCAG T TCGC \\
\hline & & 129 & TA-CG & intron & tcag $\mathbf{t}$ tctg \\
\hline & & 323 & TA-CG & intron & tgag $\mathbf{t}$ aggt \\
\hline & & 398 & CG-AT & Gln-Lys & CAAG C AGAT \\
\hline & & 416 & GC-TA & Asp-Tyr & GTTC G ACTC \\
\hline D8-7 & $\mathrm{F}_{2}-1 \mathrm{~B}$ & 1167 & GC-AT & Trp-STOP & AAGT G GAGA \\
\hline D8-8 & $\mathrm{F}_{2}-2 \mathrm{C}$ & 648 & CG-TA & Ser-Phe & GCAT C TGGT \\
\hline D8-9 & $\mathrm{F}_{2}-1 \mathrm{~A}$ & & No mutation & & \\
\hline \multirow[t]{2}{*}{ D8-11 } & $\mathrm{F}_{2}-1 \mathrm{C}$ & -944 & AT-TA & & TATA A ATAT \\
\hline & & -243 & TA-AT & & TCAG T TATT \\
\hline D8-12 & $\mathrm{F}_{2}-1 \mathrm{~A}$ & 492 & GC-AT & Arg-Gln & AACC G AGTG \\
\hline D8-14 & $\mathrm{F}_{2}-2 \mathrm{~A}$ & 494 & GC-AT & Val-Met & CCGA G TGGT \\
\hline \multirow[t]{2}{*}{ D8-18 } & $\mathrm{F}_{2}-2 \mathrm{~A}$ & 1128 & TA-CG & Leu-Pro & TTGC T CACC \\
\hline & & 1168 & GC-AT & Trp-STOP & AGTG G AGAT \\
\hline D8-19 & $\mathrm{F}_{2}-2 \mathrm{~A}$ & 596 & AT-GC & Thr-Ala & GGAG A CCAT \\
\hline D8-21 & $\mathrm{F}_{2}-2 \mathrm{~A}$ & 974 & CG-TA & Arg-STOP & GAAG C GACG \\
\hline D8-23 & $\mathrm{F}_{2}-2 \mathrm{~A}$ & 656 & CG-TA & Gln-STOP & TTTT C AGTC \\
\hline D8-26 $6^{(\mathrm{b})}$ & $\mathrm{F}_{2}-2 \mathrm{~A}$ & promotor & & & \\
\hline D8-27 & $\mathrm{F}_{2}-1 \mathrm{C}$ & 322 & GC-AT & intron & gtga $\mathbf{g}$ tag \\
\hline D8-29 & $\mathrm{F}_{2}-2 \mathrm{C}$ & 875 & CG-TA & Gln-STOP & GTTT C AGGA \\
\hline D8-30 & $\mathrm{F}_{1}-2 \mathrm{~B}$ & 974 & CG-TA & Arg-STOP & GAAG C GACG \\
\hline \multirow[t]{2}{*}{ D8-31 } & $\mathrm{F}_{1}-2 \mathrm{C}$ & -323 & TA-AT & & TCAG T TATT \\
\hline & & $-945-935$ & 10 bp deletion & & \\
\hline
\end{tabular}

(a) Since for some mutation types the damaged base could not be identified, the sequence surrounding the detected change in the coding strand is presented. Intron sequences are shown in lower case letters, exon sequences in capitals.

(b) See text for details. 
TABLE 3: Relative and absolute mutation frequencies $\left(\mathrm{F}_{1}\right.$ and $\mathrm{F}_{2}$ values expressed as mutation frequencies $\left.\times 10^{-5}\right)$ of the different mutation types constituting the mutation spectra induced by DES in postmeiotic male germ cells, in $m u s 308^{-}$and $m u s 308^{+}$conditions.

\begin{tabular}{|c|c|c|c|c|c|c|c|}
\hline \multirow{3}{*}{ Chemical } & \multirow{3}{*}{ Mutation type } & \multicolumn{3}{|c|}{ mus $308^{-}$} & \multicolumn{3}{|c|}{$\operatorname{mus} 308^{+(\mathrm{a})}$} \\
\hline & & \multirow{2}{*}{$\frac{\text { Relative frequency }}{\%}$} & \multicolumn{2}{|c|}{ Absolute frequency $\left(\times 10^{-5}\right)$} & \multirow{2}{*}{$\begin{array}{c}\text { Relative frequency } \\
\%\end{array}$} & \multicolumn{2}{|c|}{ Absolute frequency $\left(\times 10^{-5}\right)$} \\
\hline & & & $\mathrm{F}_{1}$ & $\mathrm{~F}_{2}$ & & $\mathrm{~F}_{1}$ & $\mathrm{~F}_{2}$ \\
\hline \multirow[t]{6}{*}{ DES } & GC-AT & 47.8 & 0.5 & 7.9 & 73.3 & 6.8 & 49.0 \\
\hline & AT-GC & 17.4 & - & 5.3 & 3.3 & - & 3.3 \\
\hline & AT-TA & 17.4 & 0.5 & 4.0 & 10.0 & 1.9 & 3.3 \\
\hline & AT-CG & - & - & - & 6.7 & 1.0 & 3.3 \\
\hline & GC-TA & 8.7 & - & 2.6 & - & - & - \\
\hline & Deletions & 8.7 & 0.5 & 1.3 & 6.7 & - & 6.5 \\
\hline
\end{tabular}

(a) Data of $m u s 308^{+}$conditions are from Sierra et al. [25]. One experiment was carried out mating the treated males to $I, v ; b w$ females to check the validity of the previous data for comparisons.

a statistically significant MI of 1.7). It is noticeable that the very high rise in mutation frequency was detected between 10-12 $\mathrm{mM}$ and $15 \mathrm{mM}$ DES in efficient repair conditions, but it is not unusual to find such a narrow window of increased activity in a chemical [26].

The obtained results demonstrate that Mus308 detects and processes DES-induced DNA damages. On one hand, low effectiveness DES doses, such as 10-12 $\mathrm{mM}$ (inducing low mutation frequencies), cause DNA damage, mostly oxygen alkylations [27], that seems to be processed through an error-free pathway, as pointed by the observed hypermutability. On the other hand, with high effectiveness DES doses (such as 15 and $25 \mathrm{mM}$ ), able to induce also considerable nitrogen alkylations [27], the obtained results indicate hypomutability; this fact, together with a decreased induced fertility, suggest that a functional Mus308 protein is necessary for the survival of the fertilized eggs.

The analysis of vermilion mutation frequencies (Table 1) show that, under $m u s 308^{-}$conditions and considering all concentrations together, 2 mutants were isolated in $\mathrm{F}_{1}(0.11 \times$ $10^{-4}$ mutation frequency) while most $v$ mutants, 11 , were isolated among the $\mathrm{F}_{2}$ offspring $\left(1.46 \times 10^{-4}\right.$ mutation frequency). Other $5 v$ mutants were isolated from mass cultures, but they are not included in the mutation frequency estimations. Additionally, another mutant induced by DES was identified by genetic analysis as a translocation between the $X$ and $Y$ chromosomes that does not include the $v$ locus. A comparison of these data with those obtained under mus308 proficient conditions [25] reveals that the $\mathrm{F}_{1}$ and $F_{2}$ induced mutation frequencies are much lower in mus $308^{-}$than in $m u s 308^{+}$conditions, indicating that the hypomutability observed with RL frequencies also extends to $v$ mutation frequencies.

These results are in agreement with those previously obtained with ENU in the same cell type and under the same repair conditions. In that case, hypermutability was observed with a concentration that induced a moderate level of DNA damage ( $1 \mathrm{mM}$ ENU), and similar results were found in RL and vermilion mutation frequencies analysis [14].

Results obtained here are consistent with a HR-mediated bypass of DNA damage if at least part of this damage induces cell mortality. However, a bypass tolerance system mediated by TLS could be also implicated in the processing of DES induced damaged. Thus, a DNA polymerase could process error-free some DNA damage, like oxygen alkylation, when the amount of DNA damage is low, but the processing of other types of induced DNA lesions, especially when they are present in high amounts (because other repair systems are saturated or inactive), like nitrogen alkylation, could be error-prone [28].

Moreover, there is another tolerance system, the alternative end-joining process (alt-EJ), independent of ligase 4 [29]. mus308 was very recently discovered to be involved in this system [30], which processes DNA double strand breaks generated by replication blockage. Our results are compatible also with this system because nitrogen alkylations can be the source of DNA strand breaks [27].

3.2. Mutation Spectra. Details of DES-induced mutants are shown in Table 2. In D8-9 no mutation was found, and the same mutation was present in the independent mutants D821 and D8-30, as previously reported for other vermilion spectra $[14,18,21,31,32]$. In D8-26 no mutation was detected in the coding region nor in the proximal part of the promoter, but the distal part of the promoter could not be amplified, suggesting the presence of a mutation. Additionally, D8-6 presented five different mutations none of which was found in any other mutant. No mutants were isolated either from the $24002 \mathrm{~F}_{1}$ and $15698 \mathrm{~F}_{2}$ flies analysed in the concurrent control experiments or in the historical control; therefore, we consider that the observed mutations were induced by DES. The $v$ mutation spectrum, constituted by the 23 obtained mutations, is summarized in Table 3 and includes two deletions (8.7\%) and 21 base pair changes, distributed as follows: 11 GC-AT $(47.8 \%)$ and 4 AT-GC (17.4\%) transitions, and 4 AT-TA (17.4\%) and 2 GC-TA $(8.7 \%)$ transversions.

The pairing up of these mutations with the several adducts induced by DES indicates that: (i) the GC-AT and AT-GC transitions in the DES spectrum should be, respectively, the consequence of the $\mathrm{O}^{6}$-ethylguanine and $\mathrm{O}^{4}$-ethylthymine adducts [33-36], induced by this chemical [37-39]; (ii) AT-TA transversions are most probably due to N-ethylation [40], like the rest of transversions and the deletions $[25,27]$, because DES does not ethylate 
$\mathrm{O}^{2}$-thymine [37]. The two found deletions occur between direct repeats and, as the translocation, they can be indirectly generated from N-ethylation, as described before [27].

Comparison of the relative mutation frequencies of this $m u s 308^{-}$spectrum with those previously obtained under $m u s 308^{+}$conditions (Table 3 ) reveals clear differences $(P=.07$, with the hypergeometric test, and lower if the translocation is considered), including a strong decrease in the frequency of GC-AT transitions, and increases in the frequencies of AT-GC transitions, transversions and deletions under mus $308^{-}$conditions. These results confirm that Mus308 is processing $\mathrm{O}^{6}$-ethylguanine and $\mathrm{O}^{4}$-ethylthymine, as indicated before [14], and reveal that this protein is also processing $\mathrm{N}$-ethylation damage.

$\mathrm{O}^{6}$-ethylguanine, like $\mathrm{O}^{6}$-methylguanine, is a stable DNA lesion [37] that can mispair with $\mathrm{T}$ to produce GC-AT transitions as indicated but can also pair correctly with C [41] or can even block DNA polymerases [41, 42]. Therefore, $\mathrm{O}^{6}$-ethylguanine can fit as a substrate of Mus308. $\mathrm{O}^{4}$-ethylthymine is a DNA damage with a long half-life [37], difficult to repair in mammals [43-45]. Although it is not considered a lethal lesion $[33,36]$, it is able to block DNA replication in mammalian cells in a NER deficient background [46]. NER is apparently implicated in its repair in Drosophila [27, 32], although rather inefficiently, because AT-GC transitions are one of the most frequently ENUinduced damages in the repair-active premeiotic germ cells of this organism $[21,31]$. Therefore, this adduct fits with the proposed requirements for the substrates of Mus308 [13, 14].

Since at least part of the N-ethylation damage can be persistent and can block DNA synthesis [37], its detection as substrate of Mus308, especially when the level of DNA damage is very high and repair is difficult, is not unexpected or strange. Additionally, it can be considered that $\mathrm{N}$-ethylation is a source of DNA strand breaks [27], and this type of DNA damage is substrate of Mus308 in the alt-EJ system [30].

The sequence specificity of DES- induced mutations was studied determining the base pairs $5^{\prime}$ and $3^{\prime}$ of the damaged nucleotide (Table 2). The results of this analysis show that AT pairs are present at $5^{\prime}$ in $64 \%$ of GC-AT mutations in mus $308^{-}$conditions whereas $64 \%-70 \%$ of this type of mutations is preceded by GC pairs at $5^{\prime}$ in $m u s 308^{+}$ conditions [25] and in NER deficient conditions [27], respectively. This means that the neighbouring sequences $5^{\prime}$ to $\mathrm{O}^{6}$-ethylguanine change depending on the Mus308 status, which is in good accordance with the proposed polymerase function of Mus308, specially considering that no influence of surrounding sequences was found before for this chemical in this locus $[25,27]$, nor were expected for an $S_{N} 1 / S_{N} 2$ alkylating agent [47].

In summary, the results presented in this paper demonstrate that Mus308 processes oxygen and nitrogen alkylations, and they support its role in a tolerance mechanism that is especially relevant in case of high DNA damage levels, because it prevents cell death. Additionally, these results suggest that this protein could act through a TLS pathway, because of (i) the detected neighbouring sequence influence, and (ii) its DNA polymerase activity. Finally, these results also agree with the Mus308 role in the alt-EJ system, for the processing of DNA damage-inducing strand breaks, which can be compatible with the TLS pathway [30].

\section{Acknowledgments}

This work was supported by Grants PB95/1043 and PB98/1561, sponsored by the DGES-Spanish Ministry of Education and Science. N.D-Valdes. was granted by FICYT (Asturias) with a predoctoral fellowship. The authors thank Drs. L. Alvarez, F. Barros, M. Sierra, and J.A. Ferreiro for critically reading the manuscript and HERO-España and Agua de Cuevas for providing glass and plastic material.

\section{References}

[1] P. V. Harris, O. M. Mazina, E. A. Leonhardt, R. B. Case, J. B. Boyd, and K. C. Burtis, "Molecular cloning of Drosophila mus308, a gene involved in DNA cross-link repair with homology to prokaryotic DNA polymerase I genes," Molecular and Cellular Biology, vol. 16, no. 10, pp. 5764-5771, 1996.

[2] M. Oshige, N. Aoyagi, P. V. Harris, K. C. Burtis, and K. Sakaguchi, "A new DNA polymerase species from Drosophila melanogaster: a probable mus308 gene product," Mutation Research, vol. 433, no. 3, pp. 183-192, 1999.

[3] F. Marini and R. D. Wood, "A human DNA helicase homologous to the DNA cross-link sensitivity protein mus308," Journal of Biological Chemistry, vol. 277, no. 10, pp. 87168723, 2002.

[4] S. Inagaki, T. Suzuki, M.-A. Ohto et al., "Arabidopsis TEBICHI, with helicase and DNA polymerase domains, is required for regulated cell division and differentiation in meristems," Plant Cell, vol. 18, no. 4, pp. 879-892, 2006.

[5] F. S. Sharief, P. J. Vojta, P. A. Ropp, and W. C. Copeland, "Cloning and chromosomal mapping of the human DNA polymerase $\theta$ (POLQ), the eighth human DNA polymerase," Genomics, vol. 59, no. 1, pp. 90-96, 1999.

[6] F. Marini, N. Kim, A. Schuffert, and R. D. Wood, "POLN, a nuclear PolA family DNA polymerase homologous to the DNA cross-link sensitivity protein mus308," Journal of Biological Chemistry, vol. 278, no. 34, pp. 32014-32019, 2003.

[7] M. Seki, F. Marini, and R. D. Wood, "POLQ (Pol $\theta$ ), a DNA polymerase and DNA-dependent ATPase in human cells," Nucleic Acids Research, vol. 31, no. 21, pp. 6117-6126, 2003.

[8] N. Shima, S. A. Hartford, T. Duffy, L. A. Wilson, K. J. Schimenti, and J. C. Schimenti, "Phenotype-based identification of mouse chromosome instability mutants," Genetics, vol. 163, no. 3, pp. 1031-1040, 2003.

[9] N. Shima, R. J. Munroe, and J. C. Schimenti, "The mouse genomic instability mutation chaos 1 is an allele of Polq that exhibits genetic interaction with Atm," Molecular and Cellular Biology, vol. 24, no. 23, pp. 10381-10389, 2004.

[10] M. Seki, C. Masutani, L. W. Yang et al., "High-efficiency bypass of DNA damage by human DNA polymerase Q," EMBO Journal, vol. 23, no. 22, pp. 4484-4494, 2004.

[11] G. Maga, I. Shevelev, K. Ramadan, S. Spadari, and U. Hübscher, "DNA polymerase $\theta$ purified from human cells is a high-fidelity enzyme," Journal of Molecular Biology, vol. 319, no. 2, pp. 359-369, 2002.

[12] J. B. Boyd, K. Sakaguchi, and P. V. Harris, “mus308 Mutants of Drosophila exhibit hypersensitivity to DNA cross-linking agents and are defective in a deoxyribonuclease," Genetics, vol. 125, no. 4, pp. 813-819, 1990. 
[13] I. Aguirrezabalaga, L. M. Sierra, and M. A. Comendador, "The hypermutability conferred by the mus308 mutation of Drosophila is not specific for cross-linking agents," Mutation Research, vol. 336, no. 3, pp. 243-250, 1995.

[14] L. Tosal, M. A. Comendador, and L. M. Sierra, "The mus308 locus of Drosophila melanogaster is implicated in the bypass of ENU-induced O-alkylpyrimidine adducts," Molecular and General Genetics, vol. 263, no. 1, pp. 144-151, 2000.

[15] J. Hernando, L. Álvarez, J. A. Ferreiro, I. Sancho, M. A. Comendador, and L. M. Sierra, "Female germ cell mutagenicity of model chemicals in Drosophila melanogaster: mechanistic information and analysis of repair systems," Mutation Research, vol. 545, no. 1-2, pp. 59-72, 2004.

[16] J. J. Sekelsky, K. C. Burtis, and R. S. Hawley, "Damage control: the pleiotropy of DNA repair genes in Drosophila melanogaster," Genetics, vol. 148, no. 4, pp. 1587-1598, 1998.

[17] C. Bilbao, J. A. Ferreiro, M. A. Comendador, and L. M. Sierra, "Influence of mus201 and mus308 mutations of Drosophila melanogaster on the genotoxicity of model chemicals in somatic cells in vivo measured with the comet assay," Mutation Research, vol. 503, no. 1-2, pp. 11-19, 2002.

[18] M. J. M. Nivard, I. Aguirrezabalaga, L. A. P. Ballering, A. Pastink, L. M. Sierra, and E. W. Vogel, "Evaluation of the database on mutant frequencies and DNA sequence alterations of vermilion mutations induced in germ cells of Drosophila shows the importance of a neutral mutation detection system," Mutation Research, vol. 431, no. 1, pp. 39-57, 1999.

[19] L. D. Lindsley and G. G. Zimm, The Genome of Drosophila melanogaster, Academic Press, San Diego, Calif, USA, 1992.

[20] E. W. Vogel, "Nucleophilic selectivity of carcinogens as a determinant of enhanced mutational response in excision repairdefective strains in Drosophila: effects of 30 carcinogens," Carcinogenesis, vol. 10, no. 11, pp. 2093-2106, 1989.

[21] L. Álvarez, M. A. Comendador, and L. M. Sierra, "Oethylthymidine adducts are the most relevant damages for mutation induced by N-ethyl-N-nitrosourea in female germ cells of Drosophila melanogaster," Environmental and Molecular Mutagenesis, vol. 40, no. 2, pp. 143-152, 2002.

[22] L. Álvarez, M. A. Comendador, and L. M. Sierra, "Effect of nucleotide excision repair on ENU-induced mutation in female germ cells of Drosophila melanogaster," Environmental and Molecular Mutagenesis, vol. 41, no. 4, pp. 270-279, 2003.

[23] W. T. Adams and T. R. Skopek, "Statistical test for the comparison of samples from mutational spectra," Journal of Molecular Biology, vol. 194, no. 3, pp. 391-396, 1987.

[24] N. F. Cariello, W. W. Piegorsch, W. T. Adams, and T. R. Skopek, "Computer program for the analysis of mutational spectra application to p53 mutations," Carcinogenesis, vol. 15, no. 10, pp. 2281-2285, 1994.

[25] L. M. Sierra, A. Pastink, M. J. M. Nivard, and E. W. Vogel, "DNA base sequence changes induced by diethyl sulfate in postmeiotic male germ cells of Drosophila melanogaster," Molecular and General Genetics, vol. 237, no. 3, pp. 370-374, 1993.

[26] D. Brusick, Principles of Genetic Toxicology, Plenum Press, New York, NY, USA, 2nd edition, 1987.

[27] L. M. Sierra, M. M. J. Nivard, and E. W. Vogel, "Influence of nucleotide excision repair and of dose on the types of vermilion mutations induced by diethyl sulfate in postmeiotic male germ cells of Drosophila," Mutation Research, vol. 431, no. 1, pp. 69-79, 1999.

[28] E. C. Friedberg, W. J. Feaver, and V. L. Gerlach, "The many faces of DNA polymerases: strategies for mutagenesis and for mutational avoidance," Proceedings of the National Academy of
Sciences of the United States of America, vol. 97, no. 11, pp. 5681-5683, 2000.

[29] M. McVey and S. E. Lee, "MMEJ repair of double-strand breaks (director's cut): deleted sequences and alternative endings," Trends in Genetics, vol. 24, no. 11, pp. 529-538, 2008.

[30] S. H. Chan, A. M. Yu, and M. McVey, "Dual roles for DNA polumerase theta in alternative end-joining repair of doublestrand breaks in Drosophila," PLOS Genet, vol. 6, Article ID e1001005, 2010.

[31] L. Tosal, M. A. Comendador, and L. M. Sierra, "N-Ethyl-Nnitrosourea predominantly induces mutations at AT base pairs in pre-meiotic germ cells of Drosophila males," Mutagenesis, vol. 13, no. 4, pp. 375-380, 1998.

[32] L. Tosal, M. A. Comendador, and L. M. Sierra, "In vivo repair of ENU-induced oxygen alkylation damage by the nucleotide excision repair mechanism in Drosophila melanogaster," Molecular and General Genetics, vol. 265, no. 2, pp. 327-335, 2001.

[33] R. Saffhill, G. P. Margison, and P. J. O’Connor, "Mechanisms of carcinogenesis induced by alkylating agents," Biochimica et Biophysica Acta, vol. 823, no. 2, pp. 111-145, 1985.

[34] K. S. Ellison, E. Dogliotti, T. D. Connors, A. K. Basu, and J. M. Essigmann, "Site-specific mutagenesis by $\mathrm{O}^{6}$-alkylguanines located in the chromosomes of mammalian cells: influence of the mammalian $\mathrm{O}^{6}$-alkylguanine-DNA alkyltransferase," Proceedings of the National Academy of Sciences of the United States of America, vol. 86, no. 22, pp. 8620-8624, 1989.

[35] J. C. Klein, M. J. Bleeker, J. T. Lutgerink et al., "Use of shuttle vectors to study the molecular processing of defined carcinogen-induced DNA damage: mutagenicity of single $\mathrm{O}^{4}$ ethylthymine adducts in HeLa cells," Nucleic Acids Research, vol. 18, no. 14, pp. 4131-4137, 1990.

[36] M. K. Dosanjh, P. Menichini, R. Eritja, and B. Singer, "Both $\mathrm{O}^{4}$-methylthymine and $\mathrm{O}^{4}$-ethylthymine preferentially form alkyl T.G pairs that do not block in vitro replication in a defined sequence," Carcinogenesis, vol. 14, no. 9, pp. 19151919, 1993.

[37] D. T. Beranek, "Distribution of methyl and ethyl adducts following alkylation with monofunctional alkylating agents," Mutation Research, vol. 231, no. 1, pp. 11-30, 1990.

[38] M. Bignami, A. Vitelli, A. Di Muccio et al., "Relationship between specific alkylated bases and mutations at two gene loci induced by ethylnitrosourea and diethyl sulfate in CHO cells," Mutation Research, vol. 193, no. 1, pp. 43-51, 1988.

[39] P. Fortini, A. Calcagnile, A. Di Muccio, M. Bignami, and E. Dogliotti, "Quantitative relationship between ethylated DNA bases and gene mutation at two loci in CHO cells," Environmental and Molecular Mutagenesis, vol. 21, no. 2, pp. 154-159, 1993.

[40] L. A. Loeb and B. D. Preston, "Mutagenesis by apurinic/apyrimidinic sites," Annual Review of Genetics, vol. 20, pp. 201-230, 1986.

[41] M. K. Dosanjh, E. L. Loechler, and B. Singer, "Evidence from in vitro replication that $\mathrm{O}^{6}$-methylguanine can adopt multiple conformations," Proceedings of the National Academy of Sciences of the United States of America, vol. 90, no. 9, pp. 3983-3987, 1993.

[42] G. T. Pauly, S. H. Hughes, and R. C. Moschel, "Mutagenesis in Escherichia coli by three $\mathrm{O}^{6}$-substituted guanines in doublestranded or gapped plasmids," Biochemistry, vol. 34, no. 27, pp. 8924-8930, 1995.

[43] S. M. Bronstein, T. R. Skopek, and J. A. Swenberg, "Efficient repair of $\mathrm{O}^{6}$-ethylguanine, but not $\mathrm{O}^{4}$-ethylthymine or $\mathrm{O}^{2}$-ethylthymine, is dependent upon $\mathrm{O}^{6}$-alkylguanine-DNA 
alkyltransferase and nucleotide excision repair activities in human cells," Cancer Research, vol. 52, no. 7, pp. 2008-2011, 1992.

[44] C. W. Op Het Veld, S. Van Hees-Stuivenberg, A. A. Van Zeeland, and J. G. Jansen, "Effect of nucleotide excision repair on hprt gene mutations in rodent cells exposed to DNA ethylating agents," Mutagenesis, vol. 12, no. 6, pp. 417-424, 1997.

[45] A. E. Pegg, "Repair of $\mathrm{O}^{6}$-alkylguanine by alkyltransferases," Mutation Research, vol. 462, no. 2-3, pp. 83-100, 2000.

[46] J. C. Klein, M. J. Bleeker, H. C. P. F. Roelen et al., "Role of nucleotide excision repair in processing of $\mathrm{O}^{4}$-alkylthymines in human cells," Journal of Biological Chemistry, vol. 269, no. 41, pp. 25521-25528, 1994.

[47] M. J. Horsfall, A. J. E. Gordon, P. A. Burns, M. Zielenska, G. M. E. Van der Vliet, and B. W. Glickman, "Mutational specificity of alkylating agents and the influence of DNA repair," Environmental and Molecular Mutagenesis, vol. 15, no. 2, pp. 107-122, 1990. 

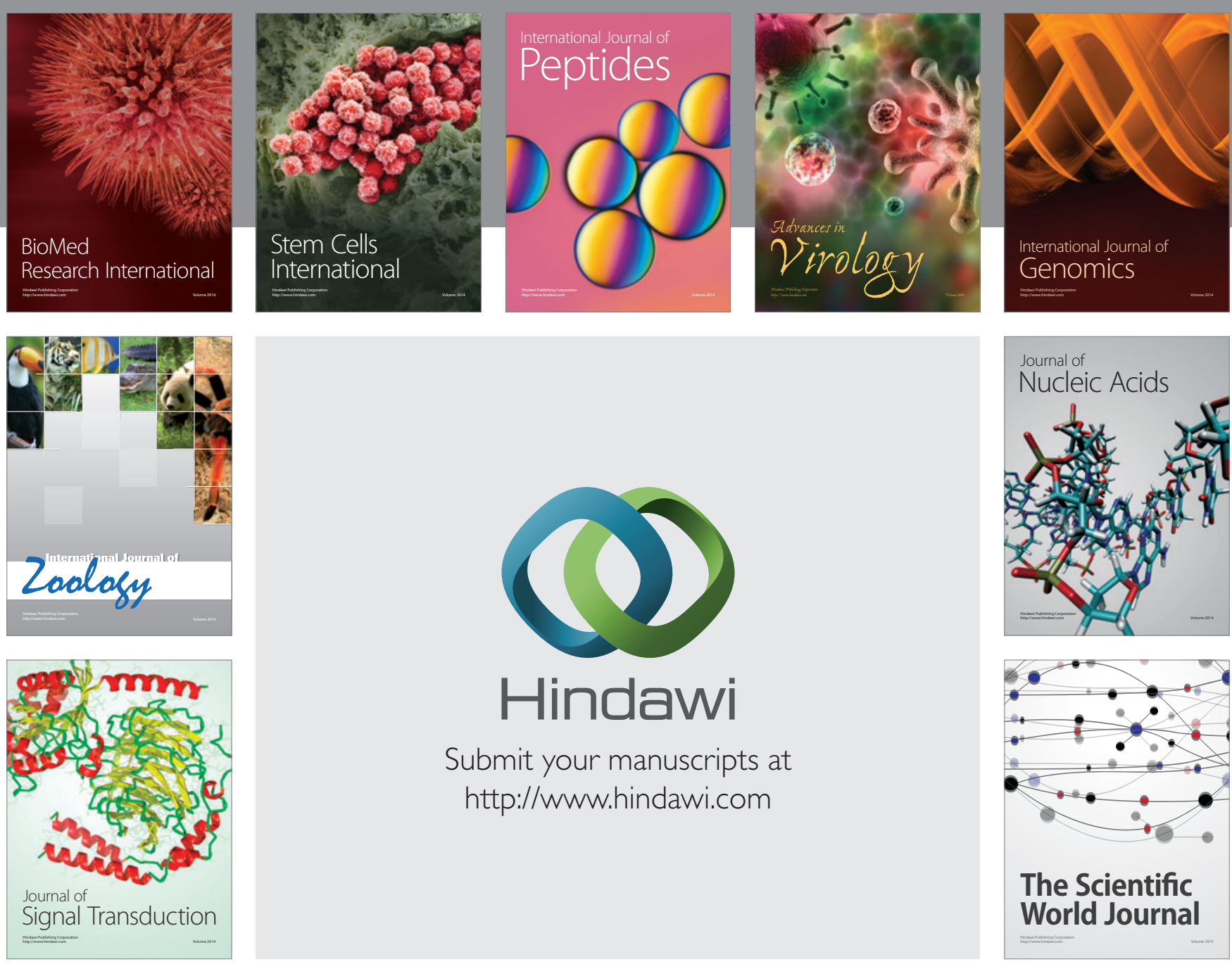

Submit your manuscripts at

http://www.hindawi.com
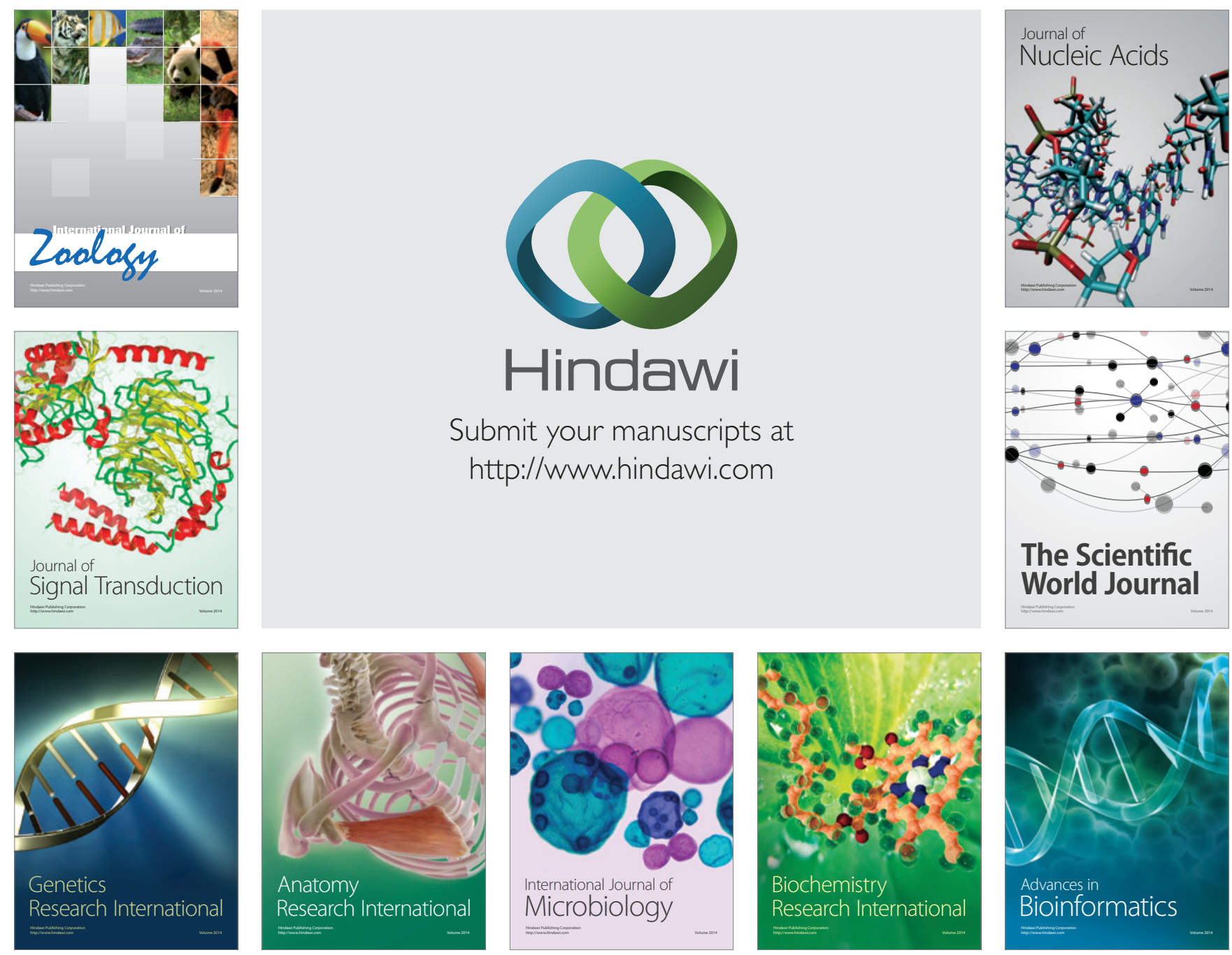

The Scientific World Journal
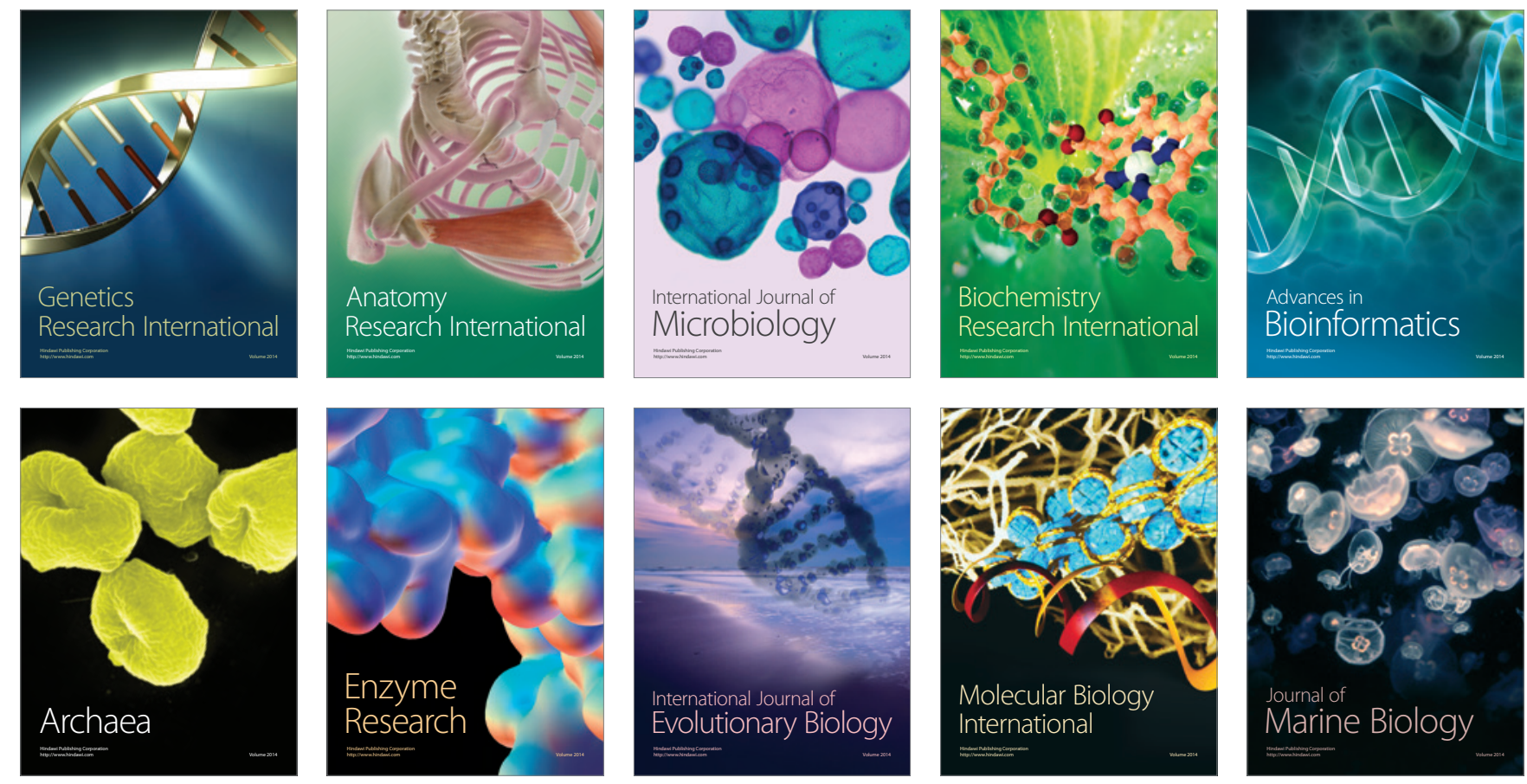